\title{
The Influence of Organizational Culture, Leadership Style, and Work Discipline on Employee Performance
}

\author{
Dewi Wahyuni and Charles Bohlen Purba
}

\section{ABSTRACT}

Purpose of this study is to analyze and understand simultaneously the influence of organizational culture, management style and work discipline on the performance of employees of PT. Don't call it Timur Shakti. The original data of the questionnaire and secondary data in the data were used as probability samples. As a sampling procedure. This study is a quantitative study of seventy-line employees of PT Bintang Timur Sakti. The analytical method used in this study is to use SPSS 24 to perform multiple linear regression. Organizational culture, management style and work discipline all have a positive impact on employee productivity. Corporate culture of PT. Bintang Timur Sakti is a variable that has a significant effect on employee productivity at PT Bintang Timur Sakti.

Keywords: Organizational Culture, Leadership Style, Work Discipline, Employee Performance.

\section{INTRODUCTION}

PT. Bintang Timur Sakti tries to provide the best service to customers in terms of project delivery on time, but in fact PT. Bintang Timur Sakti found that the organizational efficiency of on-time project completion has declined in recent times, as shown in the table below:

TABLE I: DATA ON PROJECT COMPLETION OF PT. BINTANG TIMUR SAKTI 2016-2019

\begin{tabular}{cccc}
\hline Year & $\begin{array}{c}\text { Number of } \\
\text { Projects }\end{array}$ & $\begin{array}{c}\text { Number of } \\
\text { Projects Not on } \\
\text { Time }\end{array}$ & $\begin{array}{c}\text { Percentage } \\
\text { of Number } \\
\text { of Projects } \\
\text { Not on Time }\end{array}$ \\
\hline 2016 & 10 & 2 & $20 \%$ \\
2017 & 14 & 3 & $21.4 \%$ \\
2018 & 13 & 3 & $21.4 \%$ \\
2019 & 8 & 2 & $25 \%$ \\
\hline
\end{tabular}

Source: Internal data PT. Bintang Timur Sakti, 2020.

Based on the data above, namely Among the projects that were delayed from the planned time, ten projects were accepted in 2016, while the number of projects that were not on time were still two projects and eight projects. Completed on time in 2016 and 2016. In 2017, fourteen projects were accepted, and three projects were not completed on schedule; eleven projects were completed on time, and thirteen projects were accepted in 2018, totaling three projects. Completed on time, ten projects completed on time. In 2019, eight projects were accepted, two projects were not completed on schedule, and six projects were completed on schedule. Through interviews with two key positions of director and general manager, the so-called problems that caused the decline in company productivity were identified. Based on these interviews, the authors conclude that employee productivity may be the cause of the decline in company productivity.
Submitted : July 08, 2021

Published : July 30, 2021

ISSN: 2507-1076

DOI: $10.24018 /$ ejbmr.2021.6.4.978

Dewi Wahyuni

Master of Management, Mercu Buana University, Jakarta, Indonesia.

(e-mail: dewiwahyuni630@gmail.com) Charles Bohlen Purba

Master of Management, Mercu Buana University, Jakarta, Indonesia.

*Corresponding Author

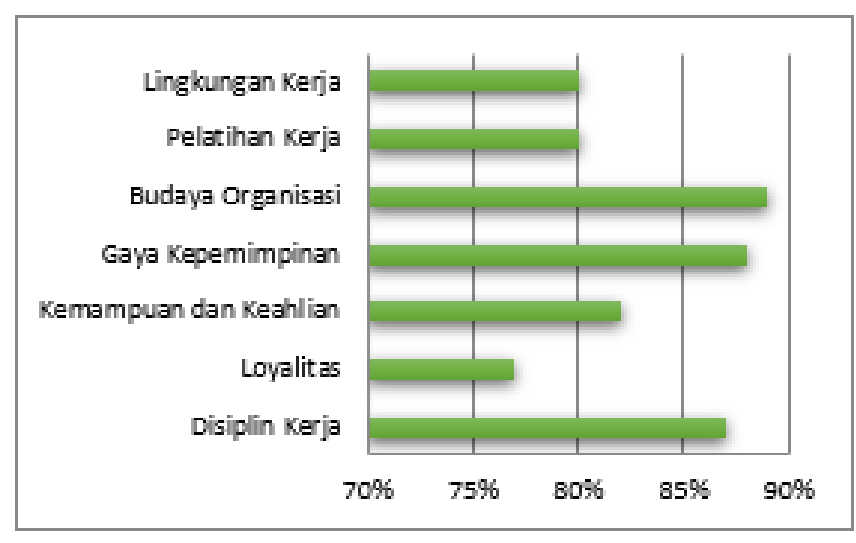

Fig. 1. Factors that affect performance.

Based on the figure above, there are three factors that have the highest value, namely Organizational Culture at $89 \%$, Leadership Style at $88 \%$, and Work Discipline at $87 \%$. To understand the impact of the above variables on employee productivity, the researcher conducted a preliminary survey of 30 permanent employees with more than one year of work experience.

\section{LITERATURE REVIEW AND HYPOTHESIS DEVELOPMENT}

\section{A. Organizational Culture}

Organizational culture is a value system promoted by participants that distinguishes an organization from other organizations [1]. Believe it or not, they are thought to influence behavior and personality.

Organizational culture, as a set of assumptions or a system of beliefs, values and norms, is being developed and used in organizations to guide the behavior of its members in dealing with external problems [2]. 


\section{B. Leadership Style}

Leadership style is a leader's way of influencing the behavior of subordinates, so that subordinates hope to achieve company goals through effective cooperation and work [3]. Leadership is the ability to influence a team to achieve a vision or goal.

\section{Work Discipline}

According to [3], work discipline is the awareness and desire of employees to comply with all company rules and social norms.

According to Latiner in [5], he defines discipline as a force developed in employees that compels employees to voluntarily comply with decisions, rules, work values, and noble behavior; it means usually related to Punishment is related. In fact, punishing employees is only part of the discipline problem.

\section{Employee Performance}

According to the definition [2], the definition of productivity is the result of qualitative and quantitative work carried out by employees in carrying out their main tasks in accordance with the responsibilities they carry.

According to [6], effectiveness is defined as the result of a process that is quoted and measured within a certain period of time according to certain regulations or agreements.

\section{E. Hypothesis Development}

This hypothesis is the first answer found in the study and needs to be verified based on the previous theoretical basis. The author proposes the following hypothesis:

H1 : employee productivity is influenced by corporate culture, leadership style and work discipline.

$\mathrm{H} 2$ : employee productivity has a significant impact which is influenced by corporate culture.

H3 : employee productivity has a significant impact which is influenced by management style

H4 : employee productivity has a significant impact which is influenced by work discipline.

\section{F. Conceptual Framework}

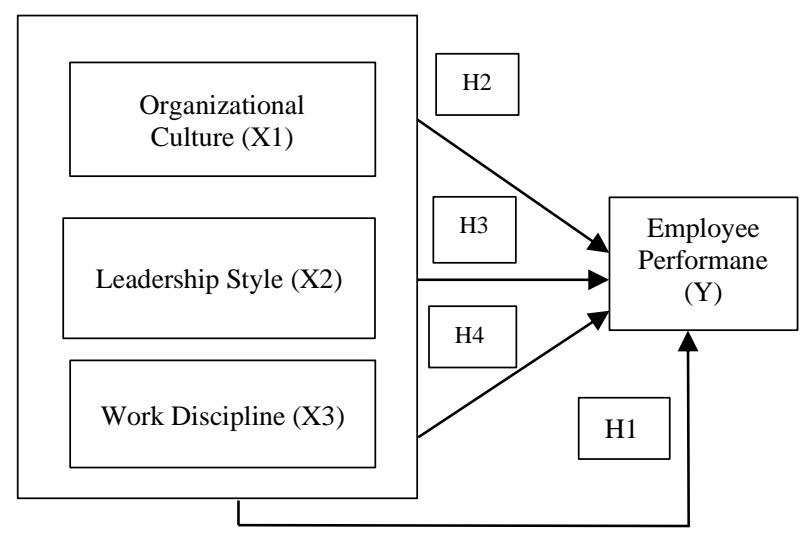

Fig. 2. Conceptual Framework.

\section{RESEARCH METHODS RESEARCH}

\section{A. Design}

This study uses quantitative methods. According to [7] quantitative research methods can be interpreted as research based on a positivist philosophy, used to study populations or samples, especially to collect data and use study tools. And analyze quantitative/statistical data. Test the proposed hypothesis. Method of studying causality. Because the study is the core of the scientific study method. This type of study looks at whether one variable causes change in another variable.

\section{B. Concept}

Definition The operational definition used in this study is consistent with the variables contained in the thinking structure. The variables in this study consist of two types of variables, namely independent variables and related variables [7]. The independent variable is the variable that affects or calls the variable. The independent variables in this study are organizational culture (X1), leadership style (X2) and work discipline (X3). According to [7] variables are variables that are changed or changed by independent variables. The variable in this study is employee productivity (Y).

\section{Population and Sample}

Researchers examined 92 permanent employees of PT Bintang Timur Sakti [7].

In conducting sampling in this study using simple random sampling, meaning that members are randomly selected to ensure that all employees have the same opportunity. The survey used the Slovin formula [8]:

$$
n=\frac{N}{1+N e^{2}}
$$

where

$\mathrm{N}$ : Population size/number of portions;

$\mathrm{n}$ : Number of samples (92 employees);

$\mathrm{e}:$ :Error tolerance limit.

$$
n=\frac{92}{1+92(0.05)^{2}}
$$

$\mathrm{n}=74,796$ rounded up to 75

\section{Data Collection}

Methods used is a survey technique that collects and analyzes data in the form of opinion on scenic spots through questionnaires, interviews, and observations. According to [7], there are several techniques used:

1. Questionnaires or questionnaires are data collections, which ask questions or explanations to interviewees that they need to answer. The purpose of the questionnaire is to collect raw data directly from the test subjects.

2. The second survey is a data collection method that uses face-to-face consultation and stakeholder responses to obtain data and information to support an analysis of local conditions.

3. On-site investigation or observation: The data collection method is the researcher directly or through observation observing the surveyed companies, issuing questionnaires, and conducting interviews with employees. 


\section{E. Data Analysis methods Data}

Analysis is an analytical method that analyzes data obtained by answering questionnaires or analyzing data in digital form. This study uses the following methods: Study testing is the application of methods used to measure natural and social phenomena, which can be used to find truth or reality and constants through observation [9]. The questionnaire must be confirmed by validation. Use SPSS v.24 for reliability testing [10].

Classical Hypothesis Testing Classical Hypothesis Testing is designed to ensure that there are no symptoms that deviate from classical assumptions, such as multicollinearity, autocorrelation, heteroscedasticity, and normally distributed data.

\section{a. Normality Test Normality}

of distributed data is a prerequisite for determining the type of statistics to be used in subsequent analysis. Since the data are usually not normally distributed, statistical parameter tests cannot be performed. When the data forms a normal curve, i.e. when the average value is the same up and down, the data are usually distributed, and it is best to use nonparametric statistics [11]. The shape of the curve is systematic, so that the average area of the left and right sides is close to $50 \%$. The test is carried out as follows [12]:

1) Normality of distributed data is a prerequisite for determining the type of statistics to be used in the following analysis. If the data distribution is normal, then it is not normal. Therefore, parameter statistical tests cannot be carried out, so parameter statistics are not required.

2) If the data forms a normal curve, that is, if the average data is the same up and down, then the data will be normally distributed. The shape of the curve is systematic, so the average area on the left and right sides is about $50 \%$. The test is performed as follows:

If asyimp. Sig< 0.05 : then the remaining data is not normally distributed.

If asyimp. Sig $>0.05:$ then the remaining data are normally distributed.

\section{b. Multicollinearity Test}

Purpose of multicollinearity test is to determine whether there is a correlation between independent variables; in a good regression model, there should be no correlation between the explanatory variables; if the explanatory variables are correlated, the variables are not orthogonal; orthogonal variables are related to other variables. Independent variable with smaller correlation. The explanatory variable is zero [12].

\section{c. Heteroscedasticity Test}

Purpose of the heteroscedasticity test is to test whether the residual variance from one observation to another in the regression model is not the same. If the variance of the residuals remains the same from one observation to the next, it is homoscedastic. A good regression model is to use residual analysis (SRESID) to predict the level of the nonheteroscedasticity variable (ZPRED):

1) If certain rules, such as certain point composition rules, are accompanied by undulations, the graph shows the presence of heteroscedasticity.
2) If there is no clear pattern and the points along the $Y$ axis are above and below zero, then there is no heteroscedasticity.

\section{d. Hypothesis}

Testing The purpose of hypothesis testing is to determine accurately whether the null hypothesis can be rejected based on the alternative hypothesis. Based on the sample data, the study can definitely reject the null hypothesis (and thus accept the alternative hypothesis). There is always the risk of someone's opinion being wrong [13].

\section{a. Multiple Linear Regression}

Multiple linear regression analysis is used to predict that two or more variables will affect the same variable [13]. b. Coefficient of Determination Test $\left(\mathrm{R}^{2}\right)$.

Deterministic analysis in multiple linear regression is used to measure the contribution of several variables $\mathrm{X}(\mathrm{X} 1, \mathrm{X} 2$, $\mathrm{X} 3$ ) to the rise and fall (change changes) Y. If the coefficient of determination $\left(\mathrm{R}^{2}\right)$ is zero, if the contribution of the independent variable to the variable the dependent does not have a low percentage or the independent variable used in the model does not change, this cannot explain the low change in the independent variable:

$$
K D=r^{2} \times 100 \%
$$

where

KD : Coefficient of Determination Value;

$\mathrm{r}^{2}$ : Value of Correlation Coefficient.

\section{e. Partial t Test}

The $t$ test or partial regression coefficient test is used to determine whether the independent variable has a partially significant effect on the dependent variable [12]. The test is carried out by comparing the $\mathrm{t}$ value of each independent variable with the table value, and the average error rate is $5 \%(\alpha=0.05)$. If the value of the $t_{\text {count }}$ table is $t$, then the independent variable has a significant effect on the dependent variable. The hypotheses used to see the effect of X1, X2, and $\mathrm{X} 3$ on $\mathrm{Y}$ (t-test) are as follows:

$\mathrm{H} 1$ : Indicates that $\mathrm{X} 1, \mathrm{X} 2$, and $\mathrm{X} 3$ jointly affect $\mathrm{Y}$.

$\mathrm{H} 2$ : indicates that $\mathrm{X} 1$ partially affects $\mathrm{Y}$.

H3 : shows that X2 partially affects $Y$.

$\mathrm{H} 4$ : shows that X3 partially affects $\mathrm{Y}$.

\section{f. $\quad$ T Test (Simultaneous)}

The f-test basically shows whether all explanatory variables or explanatory variables contained in the model have the same effect on the dependent variable [12].

The test that compares the calculated $\mathrm{F}$ value with Table $\mathrm{F}$ shows an error rate of $5 \%(\alpha=0.05)$. If $F_{\text {count }}$ is the same as $F_{\text {table, }}$, it means that the pen as a whole has a significant effect on the clear, or the third hypothesis can be accepted. The standard f-test is as follows:

1) If Sig: then 0.05 rejects $\mathrm{HO}$ and accepts $\mathrm{Ha}$, indicating that the explanatory variable also has a significant effect on certain variables.

2) If Sig> 0.05, reject $\mathrm{Ha}$ and accept $\mathrm{H} 0$, that is, the independent variable will not have a significant effect on the dependent variable simultaneously.

\section{g. Correlation Test Between Dimensions}

Correlation analysis is a statistical analysis that measures the degree of relationship between several independent 
variables $(\mathrm{X} 1, \mathrm{X} 2, \mathrm{X} 3)$ and the dependent variable (Y). With the help of dimensional correlation analysis, determine the relationship between corporate culture, leadership style and work discipline. Employee performance correlation coefficient is used to determine the degree of correlation between dimensions. This coefficient is used to determine the relationship between the measured value between the measured variable and the measured independent variable [10].

\section{OUTCOME}

\section{A. Validity of Test Results}

Effectiveness analysis results on issues such as organizational culture, leadership, work discipline, and performance evaluation showed that all issues valid because the probability is $r_{\text {table }}$.

\section{B. Test Reliability}

\begin{tabular}{cccc}
\multicolumn{4}{c}{ TABLE II: TEST RELIABILITY } \\
\hline No & Variable & Cronbach alpha & test \\
\hline 1 & Cultural Organization $(\mathrm{X} 1)$ & 0.710 & trustworthy \\
2 & Leadership style $\left(\mathrm{X}_{2}\right)$ & 0.610 & trustworthy \\
3 & Work discipline $\left(\mathrm{X}_{3}\right)$ & 0.621 & trustworthy \\
4 & Employee performance $(\mathrm{Y})$ & 0.717 & trustworthy \\
\hline
\end{tabular}

The results of questionnaire reliability verification are the results of organizational culture, management style, work discipline and employee productivity. Using Cronbach's alpha coefficient formula, the resulting sum is all equal to $0.71 ; 0.61 ; 0.621$; and 0.717 . If the value of $r_{\text {count }}>0.60$, the questionnaire is considered reliable. The calculation results show that all four have $r$ count $>0.60$. Based on the above criteria, this can be called a questionnaire on organizational culture, leadership style, work discipline and employee performance. Reliable claims.

\section{Normality Test Results}

TABLE III: NORMALITY TEST RESULTS ONE-SAMPLE KOLMOGOROV-SMIRNOV TEST

\begin{tabular}{llr}
\hline \multicolumn{2}{c}{ ONE-SAMPLE KOLMOGOROV-SMIRNOV TEST } \\
& & $\begin{array}{c}\text { Unstandardiz } \\
\text { ed Residual }\end{array}$ \\
\hline $\mathrm{N}$ & Mean & 75 \\
Normal Parameters & 0 \\
& Std. Deviation & 0,36659196 \\
& Absolute & 0,086 \\
Most Extreme Differences & Positive & 0,086 \\
& Negative & $-0,04$ \\
Test Statistic & & 0,086 \\
Asymp. Sig. (2-tailed) & & $0,200^{\mathrm{c}, \mathrm{d}}$ \\
\hline Test distribution is Normal. & \\
b. Calculated from data. & \\
c. Lilliefors Significance Correction. & \\
d. This is a lower bound of the true significance. &
\end{tabular}

Kolmogorov-Smirnov One Sample test value is 0.200 , which is greater than the 0.05 significance, indicating that $\mathrm{H} 0$ is accepted, indicating that the residual data is normally distributed.

D. Multicollinearity Test Results

TABLE IV: MULTICOLLINEARITY TEST RESUltS

\begin{tabular}{cccc}
\hline \multirow{2}{*}{ Model } & \multicolumn{2}{c}{ Collinearity Statistics } \\
\cline { 3 - 4 } & & Tolerance & VIF \\
\hline \multirow{3}{*}{1} & (Constant) & & \\
& budaya organisasi & 0,802 & 1,247 \\
& gaya kepemimpinan & 0,969 & 1,032 \\
disiplin kerja & 0,821 & 1,218 \\
\hline
\end{tabular}

It can be seen that the calculation of the tolerance value identifies that the tolerance value is $>0.10$ and the VIF calculation results show the VIF value $<10$. In other words, every organizational culture, every leadership style, and every work discipline has a VIF value which is always 1,247 ; 1,032; and 1.218.

\section{E. Heteroscedasticity Test Results}

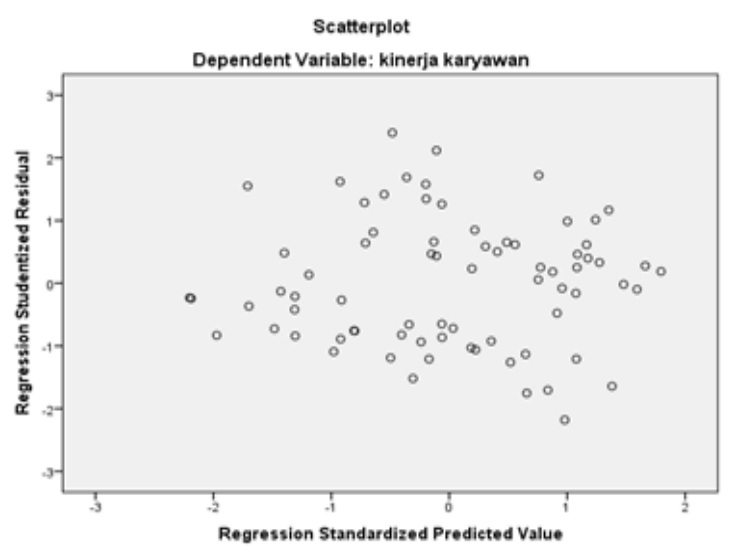

Fig. 3. Heteroscedasticity the results.

The results of the purchase decision dependent variable heteroscedasticity test indicate that the number of points is distributed and carried away by the number zero, and the points are distributed and do not form a certain pattern, so there is no heteroscedasticity. The regression model is formed.

\section{F. Results of Multiple Linear Regression Analysis}

Column B non-standard coefficient shows the constant value $(\alpha)$ is 0.756 , and the next line shows the coefficient of the independent variable (b) - organizational culture 0.335 , leadership style 0.207, and work discipline 0.205. From the table above, the multiple linear regression equation is as follows:

$$
\mathrm{Y}=0.756+0.335 \mathrm{X} 1+0.207 \mathrm{X} 2+0.205 \mathrm{X} 3+\mathrm{e}
$$

TABLE V: RESULTS OF MULTIPLE LINEAR REGRESSION ANALYSIS

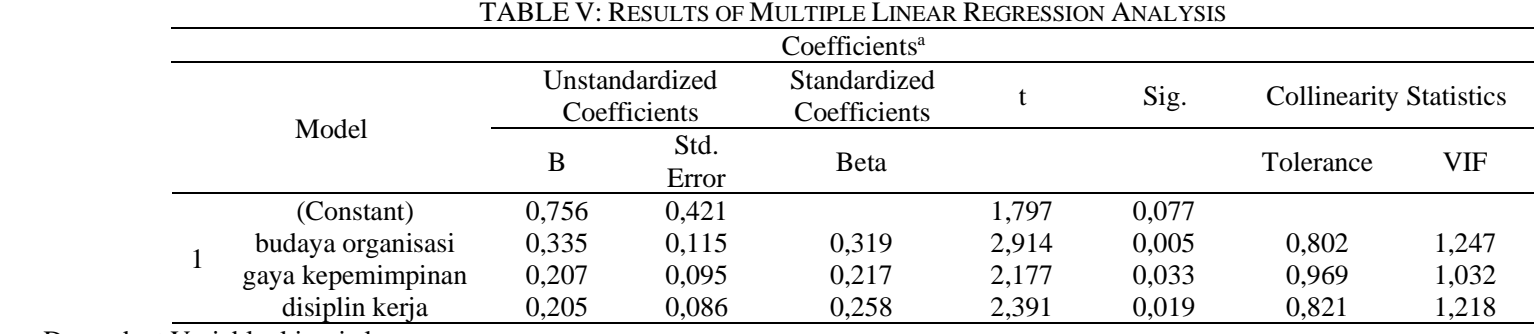

a. Dependent Variable: kinerja karyawan. 
The interpretation of the multiple linear regression equation is:

1 Constant = It was found that when the organizational 0.756

$2 \mathrm{~b} 1=0.335$

$3 \quad b 2=0.207$

$4 \quad b 3=0.205$ culture variable, leadership style, and the discipline of work is equal to 0 , the value of the employee's work is 0.756 .

indicates that employee performance increases when organizational culture increases 1 point by 0.335 without additional variables (constant).

means that if the leadership style is increased by 1 point, the employee's performance will increase by 0.207 , as long as there are no additional variables (constant).

which means that if work discipline is increased by 1 point, the employee's performance will increase by 0.205 . Assuming there are no other additional variables (constant).

G. Determination Coefficient Test Results $\left(R^{2}\right)$

TABLE VI: DETERMinATION COEFFICIENT TeSt RESUlts $\left(\mathrm{R}^{2}\right)$

\begin{tabular}{cc|c|c|c}
\hline \multicolumn{6}{|c}{ Model Summary $^{\mathrm{b}}$} \\
\hline Model & $\mathrm{R}$ & R Square & $\begin{array}{c}\text { Adjusted } \\
\text { R Square }\end{array}$ & $\begin{array}{c}\text { Std. Error of } \\
\text { the Estimate }\end{array}$ \\
\hline 1 & $0,565^{\mathrm{a}}$ & 0,319 & 0,29 & 0,374 \\
\hline
\end{tabular}

a. Predictors: (Constant), disiplin kerja, gaya kepemimpinan, budaya organisasi.

b. Dependent Variable: kinerja karyawan.

The result of determination coefficient analysis on the regression model obtained adjusted R-squared value of $29 \%$. The adjusted R-squared value indicates that independent variables of corporate culture, leadership style, and work discipline influence employee performance of $29 \%$ while the rest of $61 \%$ is influenced by other variables other than those used in this study.

\section{H. Partial Test Results ( $t$ Test)}

\begin{tabular}{ccccc}
\multicolumn{5}{c}{ TABLE VII: PARTIAL TEST RESUlTS (T TEST) } \\
\hline Variable & Unstandardized Coefficients & \multirow{2}{*}{ t } & \multirow{2}{*}{ Sig. } \\
\hline (Constant) & 0,756 & 0,421 & 1,797 & 0,077 \\
budaya organisasi & 0,335 & 0,115 & 2,914 & 0,005 \\
gaya kepemimpinan & 0,207 & 0,095 & 2,177 & 0,033 \\
disiplin kerja & 0,205 & 0,086 & 2,391 & 0,019 \\
\hline
\end{tabular}

Corporate culture is influenced by employee performance is 2,914 , with a probability of 0.005 . The coefficient of organizational culture variable is 0.335 with a positive sign, namely $\mathrm{H}$. The best organizational culture, the best employee performance. Probability value $=0.005 \mathrm{Lt} ;=0.05$. This means that corporate culture has a significant effect on employee productivity. Based on this interpretation, Hypothesis 1 is accepted: organizational culture has a positive effect on employee performance. Influence of Born Leadership Style on Employee Productivity The value of born leadership style on employee performance is 2.177 and probability is 0.033 . The coefficient of variable leadership style is 0.207 , with a positive sign, so it is better. The better the leadership style, the better the count. Probability value = $0.033 \mathrm{Lt} ;=0.05$ This means that leadership style has a significant effect on employee work productivity. Based on this explanation, Hypothesis 2 is accepted: Leadership style has a positive effect on employee productivity. See the impact of work discipline on work productivity. The effect of work discipline on employee productivity is 2,391 and the probability value is 0.019 . The coefficient of work discipline variable is 0.205 , the coefficient is positive, and the best value is $0.019 \mathrm{Lt} ;=0.05$. This means that work discipline has a big effect on employee productivity. Based on this explanation, Hypothesis 3 is accepted: Work discipline has a positive effect on worker productivity.

\section{F Test Results}

\begin{tabular}{ccccccc}
\hline \multicolumn{7}{c}{ TABLE VIII: F TEST RESULTS } \\
\hline \multirow{2}{*}{ Model } & $\begin{array}{c}\text { Sum of } \\
\text { Squares }\end{array}$ & df & $\begin{array}{c}\text { Mean } \\
\text { Square }\end{array}$ & F & \multirow{2}{*}{ Sig. } \\
\hline \multirow{2}{*}{1} & Regression & 4,653 & 3 & 1,551 & 11,072 &, $000^{\mathrm{b}}$ \\
& Residual & 9,945 & 71 & 0,14 & & \\
& Total & 14,597 & 74 & & & \\
\hline
\end{tabular}

a. Dependent Variable: kinerja karyawan.

b. Predictors: (Constant), disiplin kerja, gaya kepemimpinan, budaya organisasi.

Based on the analysis of variance or the $\mathrm{F}$ test, the calculated $\mathrm{f}$ value is 11.072 and the probability value is 0.000 . Because the significance value is less than 0.05 , this indicates that corporate culture, leadership style, and work discipline together or jointly have a significant effect on employee performance.

TABLE IX: CORRELATION MATRIX

\begin{tabular}{|c|c|c|c|c|c|c|c|}
\hline Variabel & Dimensi & $\begin{array}{l}\text { Quality } \\
\text { (Y1.1) }\end{array}$ & $\begin{array}{l}\text { Quantity } \\
\text { (Y1.2) }\end{array}$ & $\begin{array}{c}\text { Timeliness } \\
\text { Terkait dengan } \\
\text { waktu (Y1.3) }\end{array}$ & $\begin{array}{c}\text { Cost Effectiveness } \\
\text { (Y1.4) }\end{array}$ & $\begin{array}{c}\text { Kemampuan } \\
\text { Individu (Y1.5) }\end{array}$ & $\begin{array}{c}\text { Kemampuan } \\
\text { Individu dalam } \\
\text { kerja sama (Y1.6) }\end{array}$ \\
\hline \multirow{6}{*}{$\begin{array}{c}\text { Culture of } \\
\text { Organisation (X1) }\end{array}$} & $\mathrm{X} 1.1$ & 0.21 & 0.203 & -0.08 & 0.194 & 0.145 & 0.159 \\
\hline & $\mathrm{X} 1.2$ & $0.293^{*}$ & 0.05 & 0.153 & $0.401^{* *}$ & $0.246^{*}$ & 0.176 \\
\hline & $\mathrm{X} 1.3$ & $0,242^{*}$ & 0.208 & $0.291^{*}$ & $0,285^{*}$ & 0.093 & 0.095 \\
\hline & $\mathrm{X} 1.4$ & 0.216 & 0.091 & 0.207 & 0.105 & 0.132 & 0.107 \\
\hline & $\mathrm{X} 1.5$ & $0.273^{*}$ & 0.21 & 0.18 & $0,381^{* *}$ & 0.155 & -0.072 \\
\hline & $\mathrm{X} 1.6$ & $0,232^{*}$ & 0.068 & $0.252^{*}$ & $0.258^{*}$ & 0.094 & 0.069 \\
\hline \multirow{4}{*}{$\begin{array}{l}\text { Gaya Kepemimpinan } \\
\text { (X2) }\end{array}$} & $\mathrm{X} 1.7$ & 0.134 & 0.177 & 0.01 & 0.178 & 0.171 & 0.189 \\
\hline & $\mathrm{X} 2.1$ & 0.085 & -0.045 & 0.108 & 0.154 & 0.089 & 0.115 \\
\hline & $\mathrm{X} 2.2$ & $0.246^{*}$ & 0.181 & $0.281^{*}$ & $0.296^{* *}$ & 0.123 & 0.095 \\
\hline & $\mathrm{X} 2.3$ & 0.143 & -0.026 & 0.013 & 0.187 & $0.228^{*}$ & 0.212 \\
\hline \multirow{6}{*}{ Disiplin Kerja (X3) } & X3.1 & $0.256^{*}$ & $0.342^{* *}$ & 0.192 & $0.312^{* *}$ & 0.133 & 0.155 \\
\hline & X3.2 & $0,269^{*}$ & $0.243^{*}$ & 0.114 & $0.265^{*}$ & $0.228^{*}$ & 0.18 \\
\hline & X 3.3 & $0.320^{* *}$ & $0.264^{*}$ & 0.156 & $0.245^{*}$ & 0.158 & 0.173 \\
\hline & X3.4 & 0.153 & 0.191 & 0.18 & $0.244^{*}$ & 0.1 & 0.156 \\
\hline & X3.5 & $0.257^{*}$ & $0.239^{*}$ & -0.023 & 0.121 & 0.141 & 0.116 \\
\hline & X3.6 & -0.079 & 0.056 & -0.076 & 0.094 & 0.026 & 0.015 \\
\hline
\end{tabular}




\section{J. Inter-Dimensional Correlation TestInter-Dimensional}

Among organizational culture variables, paying attention to details of employee performance (X1.2) is an important aspect in the profitability dimension (Y1.4), because the coefficient value is 0.401 and the lowest employee value is in the dimension (X17). Performance. When measuring opportunity time (Y1.3) because the factor is 0.010 .

Among leadership style variables, the most relevant parameter is the general leadership parameter (X2.2) which is related to employee productivity in measuring profitability (Y1.4), because the coefficient value 0.296, and the smallest value is in the authorized leadership. of (X2.3). Employee performance in odds is related to time (Y1.3) because the coefficient is 0.013 .

Among the discipline variables, the strongest performance dimension is the measurement of target ability (X3.1) employee productivity on the quantity dimension (Y1.2), because the coefficient value is 0.342 , and lower values are legal sanctions. Field dimension (X3.6) Employee performance in personal cooperation ability (Y1.6) because the coefficient is 0.015 .

\section{DISCUSSION}

From the results of data processing using SPSS 24, a number of study results were obtained with the topic "The Influence of Organizational Culture, Management Style and Work Discipline on Employee Productivity at PT Bintang Timur Sakti". They will support or reject this hypothesis in the future. Based on the results of the regression and $t$ test, it can be seen that corporate culture has a positive effect on employee performance, this indicates that corporate culture can improve employee performance at PT Bintang Timur Sakti. These results support the original study by [14] entitled "The Influence of Organizational Culture, Leadership Style and Work Discipline on Employee Performance of PT Bank Tabungan Negara (Persero) TBK Manado". "Office", the result. Ensuring that corporate culture and work discipline have a positive and significant effect on employee performance, while leadership style has a negative effect on employee performance. T-test regression analysis shows that leadership style has a significant negative effect on employee performance. The impact on employee productivity. Demonstrate the positive impact of a good leadership style. Leadership can increase employee productivity. These results confirm the study [15] with the title "The Influence of L Leadership Style, Organizational Culture and Work Discipline on District Education, Youth and Sports Organizational Activities", and the results of the Leadership Style Study have a significant effect on Education and Performance of Youth and Sports Management Tojo Una una district, as well as organizational culture and work discipline have a significant positive effect on the performance of education, youth and sports staff in Tojo Una una district. In addition, (16) with the title "The Influence of Leadership, Work Discipline, and Culture on Employee Productivity in Rawalumbu Village" has no significant effect on employee productivity in Rawalumbu Village.

\section{CONCLUSION}

Studies on the influence of organizational culture, leadership style and work discipline on employee productivity (e.g., PT Bintang Timur Sakti) The results are:

1. Corporate culture, leadership style and work discipline have a significant effect on work productivity. Employees of PT Bintang in the East Sakti.

2. Corporate culture has a significant positive effect on employee productivity. PT Bintang Timur Sakti in particular, attention to detail has a strong correlation with profitability measurement, and measurement has a strong correlation with gender. This has an impact on the low productivity of employees.

3. Leadership style has a significant positive effect on employee productivity. PT Bintang Timur Sakti especially the measurement of joint leadership is closely related to the measurement of profitability, while the measurement of the authorized leadership has little effect on the measurement. Over time, the relevance of employee productivity becomes low.

4. Work discipline has a significant positive effect on employee productivity at PT Bintang Timur Sakti, especially the evaluation of target capability, which is closely related to quantitative measures, while the level of legal sanctions has a very weak effect. Correlation.

\section{REFERENCES}

[1] Robbins SP, Judge TA, Millett B. OB: The Essentials. Pearson Higher Education AU; 2015.

[2] Mangkunegara AAAP. Manajemen Sumber Daya Manusia Perusahaan. PT. Remaja Rosdakarya; 2016.

[3] Hasibuan MSP. Manajemen Sumber Daya Manusia Cetakan ketiga belas, Edisi Revisi. Jakarta: PT Bumi Aksara; 2018.

[4] Robbins SP, Judge TA. Perilaku Organisasi, Edisi 16. Jakarta: Salemba Empat; 2017.

[5] Soetrisno E. Manajemen Sumber Daya Manusia. Jakarta: Kencana Prenada Media Group; 2016.

[6] Edison E, Anwar Y, Komariyah I. Manajemen Sumber Daya Manusia. Bandung: Alfabeta; 2016.

[7] Sugiyono. Metode Penelitian Pendidikan Pendekatan Kuantitatif, Kualitatif, dan R\&D. Bandung: Alfabeta; 2014.

[8] Sevilla CG. Research Methods. Rex Bookstore, Inc.; 2007.

[9] Sugiyono PD. Pengaruh inflasi, nilai tukar, dan harga minyak dunia terhadap indeks saham syariah Indonesia (ISSI). J Chem Inf Model. 2016;53(9):1689-99.

[10] Sugiyono. Metode Penelitian Kuantitatif Kualitatif dan R\&D. Bandung: Alfabeta; 2011.

[11] Sugiyono. Metode Penelitian Pendidikan Pendekatan Kuantitatif, Kualitatif, dan R\&D. Bandung: Alfabeta; 2013.

[12] Ghozali I. Aplikasi Analisis Multivariat Dengan Program SPSS Semarang: Badan Penerbit Universitas Diponegoro; 2011.

[13] Sekaran U, Bougie R. Metode Penelitian untuk Bisnis: Pendekatan Pengembangan-Keahlian, Edisi 6, Buku 2. Jakarta: Salemba Empat; 2017.

[14] Wales G V, Mandey SL, Wenas RS. Pengaruh Budaya Organisasi, Gaya Kepemimpinan, dan Disiplin Kerja Terhadap Kinerja Karyawan PT. Bank Tabungan Negara (Persero) Tbk. Kantor Cabang Manado. J EMBA J Ris Ekon Manajemen, Bisnis dan Akunt. 2018; 5(3).

[15] Umala M. Pengaruh Gaya Kepemimpinan, Budaya Organisasi dan Disiplin Kerja Terhadap Kinerja Pegawai Dinas Pendidikan, Pemuda dan Olahraga Kabupaten Tojo Una-Una. Katalogis Univ Tadulako. 2017; 5(10)

[16] Suprihat A, Djamil M. Pengaruh Kepemimpinan, Disiplin Kerja, dan Budaya Organisasi terhadap Kinerja Pegawai Kecamatan Rawalumbu. Indik J Ilm Manaj dan Bisnis Univ Mercu Buana. 2018; 2(2). 